\section{Rapa Nui y la lepra}

\section{Rapa Nui and Laepra}

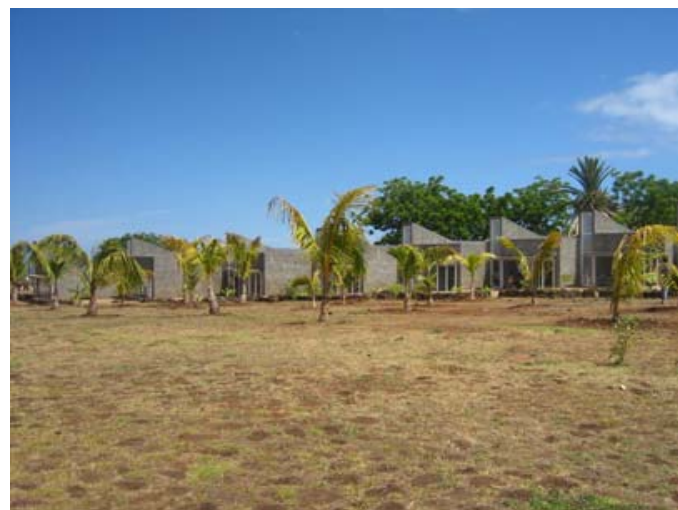

Nuevo liceo de Rapa Nui.

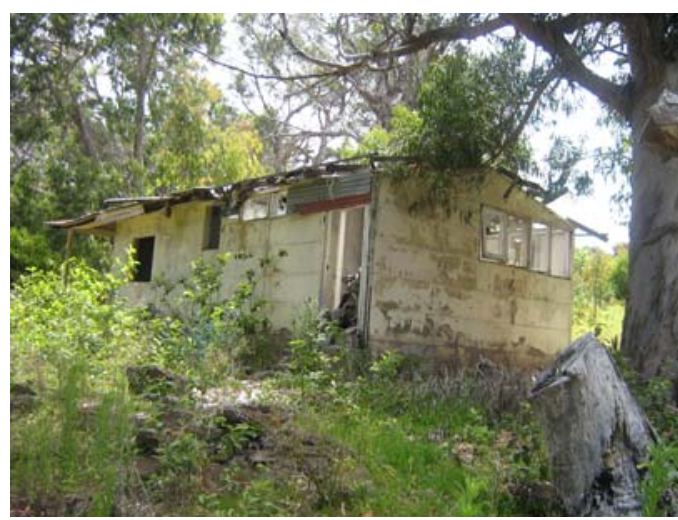

Ruinas del antiguo sanatorio para leprosos.

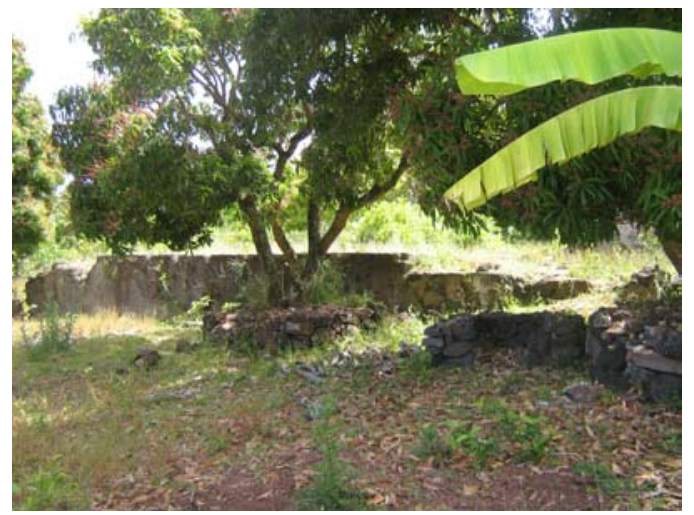

Ruinas del antiguo lazareto.

\section{Referencias}

1.- Sierra, Malú. Rapanui náufragos del planeta. Santiago; Editorial Persona, 2002.

2.- Ledermann, Walter. Una historia personal de las bacterias. Santiago; RIL editores; 2007.

3.- Gómez de Silva, Guido. Breve diccionario etimológico de la lengua española. $2^{\mathrm{a}}$ ed. Fondo de Cultura Económica; México D.F.; 1998.

4.- Cristino, C. Recasens A. Vargas, P. "Isla de Pascua, proceso, alcances y efectos de la aculturación”. http:/www.facso.uchile.cl/publicaciones/biblioteca/docs/ libros/pascua.pdf (Acceso 22 de diciembre 2008). años sucesivos".
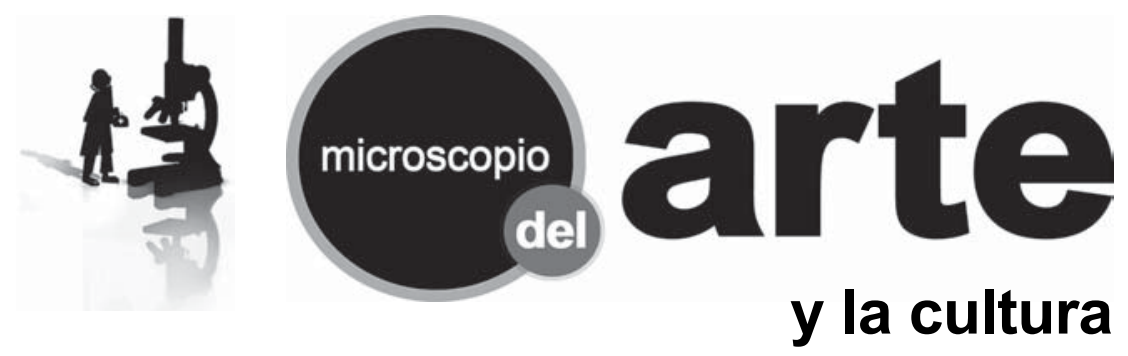

El origen de la lepra, del griego leprós (que se escama o se pela), se pierde en los albores de la historia, encontrándose descripciones de ésta en los antiguos papiros egipcios, en la Biblia, en las observaciones de Hipócrates y en las de historiadores como Heródoto y Plinio. A partir de su origen posiblemente en Persia o Egipto, se difunde rápidamente a Grecia, Roma y luego a toda Europa, donde en la Edad Media causa tal estrago, que fueron creadas las leproserías, luego llamados lazaretos, debido a Lazarus, nombre de un mendigo enfermo que aparece en el Evangelio según San Lucas.

La lepra es introducida en Rapa Nui (Isla de Pascua) hacia 1889, posiblemente desde Tahiti, lo que determina la prohibición de que los isleños abandonen la isla.

Para ese entonces, la historia y las peripecias del pueblo Rapa Nui y su isla, no tienen parangón en la historia de otras etnias aborígenes.

La evidencia arqueológica indica que el desarrollo de la cultura Rapa Nui es producto de un solo grupo, de origen polinésico, que habría poblado la isla hacia el año 400 D.C., y que durante 1.300 años de aislamiento, desarrolló una cultura de sorprendente complejidad.

Uno de los nombres dados a la isla es "Te pito o te henua" (el ombligo del mundo) y los primitivos habitantes de la isla consideraban que ésta era el único lugar habitado, siendo ellos los únicos seres humanos sobre la tierra.

Desde su descubrimiento occidental en 1722, la isla pasa por los más inverosímiles colonizadores y administradores. A partir de la anexión a Chile en 1888, la situación sanitaria no mejora, como describe el informe presentado por el médico de la corbeta "General Baquedano", quién concluía que los isleños tenían una alimentación deficiente, habitaciones poco higiénicas, "presentándose además casos de tuberculosis y lepra entre jóvenes que evidentemente habían sido contagiados por los ancianos que la habian contraído en Tahiti. Debido a que no existía ninguna prevención, esta enfermedad se extendió rápidamente, presentándose muchos nuevos casos en los

En 1916 viaja a la isla Monseñor Rafael Edwards, quién escribió en "El Mercurio" de Valparaíso: "Se les ha robado cuanto tenían. El suelo en que nacieron, sus casas, sus barcas, sus animales, sus vestidos mismos, todo, todo ha sido objeto de la brutal codicia de los hombres sin Dios ni ley, sin entrañas y sin pudor. Arrinconados como animales, perseguidos en el último rincón de su propia isla viven de la merced de quienes los han despojado".

La publicación de la carta de Monseñor Edwards, más una extensa campaña de prensa en los periódicos hace que el 29 de enero de 1917, se dicte la ley 3220, por la cual se autoriza la construcción de un lazareto y una escuela en Isla de Pascua que, desde ese momento pasa a depender de la Dirección del Territorio Marítimo.

Finalmente, a fines de la década del setenta, se construyó un sanatorio, que reemplazó al antiguo leprosario.

En 1992 sólo quedaban tres leprosos en el sanatorio, los que fueron tratados, dados de alta y volvieron con sus familias. En el lugar del sanatorio se levanta una hermosa obra de arquitectura que alberga al liceo de Rapa Nui.

Monseñor Edwards fue una de las pocas autoridades que, desde el continente, se preocupó de este tema, al cual se refiere en varias cartas que actualmente se conservan en el Museo Antropológico de Isla de Pascua.

Texto y fotografias: Ernesto Payá G. 